\title{
GRAIN QUALITY OF MUTANT LINES INDUCED IN MALTING BARLEY VARIETIES
}

\author{
B. Dyulgerova*, N. Dyulgerov
}

\begin{abstract}
Forty-three mutant lines selected on the base of their high grain yield along with parent varieties Kuber, Zagorets, Asparuh, and Imeon were grown in field trials at the Institute of Agriculture Karnobat in three consecutive years. Eight physical and chemical characteristics of grain related to the grain quality of malting barley were measured. There was considerable variation among barley mutant lines for all studied traits. Mutant lines with higher extract content, grain uniformity, 1000 grain weight, and lower protein content in grain compared to parent varieties were found. The correlations among traits showed that improvement of extract content of mutant lines was associated with increased grain uniformity, starch content, grain size, and 1000 grain weight and reduced protein content. The results from cluster analysis indicated that mutants originated from the same parent were grouped into different clusters. Therefore, the sodium azide treatment effectively induced diverse types of changes in the grain characteristics.
\end{abstract}

Kay words: malt barley, mutant lines, grain quality

\section{INTRODUCTION}

Mutation breeding has been used intensively for the improvement of important agronomic traits in many crops (1). The mutations are effective not only for changing major genes but also induce variation in the quantitative traits (2). As a result of the application of mutation techniques in breeding, hundreds of barley varieties have been developed worldwide (3).

Induced mutants affecting grain composition have been valuable sources for improving barley grain quality. High beta-glucan content is unwanted for grain used for brewing because it interferes with the separation of wort and causes haze formation. Mutants with a decrease in the content of beta-glucans in the endosperm enhance germination speed and as a result, improved malting quality had been selected after treatment with sodium azide of seeds of barley variety Troubadour (4).

Other mutants with the altered chemical composition of barley grain are waxy (wax) mutants with reduces amylose content (5) and

\footnotetext{
*Correspondence to: Boryana DYULGEROVA, Institute of Agriculture, 8400 Karnobat, Bulgaria, e-mail: bdyulgerova@abv.bg
}

high-amylose mutants (amo) with increases the content of amylose up to $70 \%$ in the endosperm (6).

Mutants with increased percent of lysine (7) and the high content of protein were found (8). Valuable barley mutants are also low-phytate mutants for feed barley (9) and proanthocyanidin-free mutants for malting and food barley $(10,11)$.

Of particular interest are Lipoxygenase-1 null barley mutants, which have an improved brewing quality, because lipoxygenase reduces foam stability and causes the appearance of substance that causes unpleasant flavor during beer aging. (12).

Sodium azide is a chemical mutagen that effectively enhances variability in important traits in barley (13). This mutagen was also used successfully in the barley breeding program of the Institute of Agriculture Karnobat for the development of new barley varieties $(14,15)$.

The aim of the present study was to study the grain quality of mutant lines induced in malting barley varieties Kuber, Zagorets, Asparuh, and Imeon. 


\section{MATERIAL AND METHODS}

A field trial in complete block design with 4 replications on plots of $10 \mathrm{~m}^{2}$ was conducted in three growing seasons from 2014/2015 to 2016/2017 at the Institute of Agriculture Karnobat, Bulgaria. Forty-three mutant lines along with parent varieties Kuber, Zagorets, Asparuh, and Imeon were used in this study.

To obtain the M1 population, seeds from winter malting varieties Kuber, Zagorets, Asparuh, and Imeon were treated with $2 \mathrm{mM}$ sodium azide for $2 \mathrm{~h}$. All survived plants in M1 were harvested in bulk. In M2 generation one spike for each selected plant was harvested in order to develop M3 generation. The selection of for higher grain yield compared to parent varieties was applcaid from M3 to M6 generation. Grain quality traits of the selected 13 lines from Kuber, 10 lines from Zagorets, 10 from Asparuh, and 10 from Imeon were studied in the present study.

The protein content $(\%)$ was determined by the Kjeldahl method, and a conversion factor of 6.25 was used to convert total nitrogen to crude protein. The starch content (\%) was measured by Ewers's polarimetric method. Barley grain uniformity was expressed as the percent of the grain weight remaining on sieves with a $2.8 \times 25 \mathrm{~mm}$ and $2.5 \times 25 \mathrm{~mm}$ mesh to the weight of grain passed through the sieves. Grain length $(\mathrm{mm})$ and grain width $(\mathrm{mm})$ were measured on 60 grains per line/parent using the open-source software Image J (16) and the GL: GW ratio was calculated. The 1000-grain weight (g) was taken from 200 random grains multiplied by 5 . Grain samples were micro-malted using the automated malting equipment. Grounded malt samples were mashed and extract content was determined by a refractometric method (17).

The mean values were compared by the least significant difference (LSD) at the 0.05 probability level. Pearson correlation coefficients between studied traits were estimated. Cluster analysis using Ward's method with squared Euclidean distance and standardized means variables was performed (18). All data were processed with the program SPSS 16.00 for Windows (19).

\section{RESULTS}

Three mutant lines from variety Kuber (16/1-3, $16 / 1-10$, and 16/1-14) with lower uniformity of grains compared to the parent ware found (Table 1). Most of the lines had higher protein content than Kuber. Only line 16/1-4 showed significantly lower mean protein than parent variety. Mutant line 16/2-12 had higher starch and extract content, 1000-grain weight, and grain length and width compared to the parent. Grain length-width ratio was different from that of Kuber in mutant lines 16/1-3, 16/1-8, and $16 / 1-13$.

Table 1. Physical and chemical characteristics of grain of barley mutant lines and the parent variety Kuber

\begin{tabular}{lllllllll}
\hline $\begin{array}{l}\text { Mutant line/ } \\
\text { Parent }\end{array}$ & GU & PC & SC & TGW & GL & GW & GR & EC \\
\hline Kuber & 92.25 & 11.93 & 57.20 & 45.12 & 8.50 & 3.50 & 2.43 & 77.95 \\
$16 / 1-1$ & 92.90 & 11.93 & 57.40 & 45.51 & 8.39 & 3.55 & 2.36 & 77.20 \\
$16 / 1-3$ & 89.15 & 13.03 & 57.23 & 43.40 & 7.77 & 2.80 & 2.78 & 77.25 \\
$16 / 1-4$ & 91.65 & 11.02 & 59.02 & 44.02 & 7.35 & 3.01 & 2.44 & 79.40 \\
$16 / 1-8$ & 92.85 & 13.08 & 57.79 & 45.27 & 8.88 & 3.23 & 2.75 & 77.85 \\
$16 / 1-10$ & 89.65 & 11.97 & 58.59 & 43.18 & 7.93 & 3.32 & 2.39 & 77.15 \\
$16 / 1-13$ & 91.15 & 11.99 & 58.78 & 44.73 & 8.98 & 3.12 & 2.88 & 77.45 \\
$16 / 1-14$ & 91.55 & 12.36 & 57.13 & 44.07 & 7.74 & 2.97 & 2.67 & 76.85 \\
$16 / 1-21$ & 91.55 & 12.93 & 57.04 & 45.42 & 8.34 & 3.29 & 2.53 & 77.20 \\
$16 / 2-11$ & 91.40 & 12.98 & 57.15 & 44.96 & 8.49 & 3.43 & 2.48 & 75.70 \\
$16 / 2-12$ & 92.35 & 11.90 & 59.23 & 47.34 & $9.16^{+}$ & 3.94 & 2.32 & 79.75 \\
$16 / 3-8$ & 92.60 & 12.28 & 58.15 & 44.91 & 8.64 & 3.76 & 2.30 & 79.20 \\
$16 / 3-12$ & 92.60 & 12.30 & 57.32 & 43.15 & 7.29 & 3.07 & 2.37 & 77.15 \\
$16 / 3-14$ & 90.90 & 12.53 & 58.87 & 43.46 & 7.26 & 3.03 & 2.40 & 75.60 \\
LSD 0.05 & 1.24 & 0.61 & 1.53 & 1.09 & 0.58 & 0.39 & 0.25 & 1.49 \\
\hline
\end{tabular}

GU - grains uniformity (\%); PC - protein content (\%); SC - starch content (\%), TGW - 1000-grain weight (g); GL - grain length (mm); GW - grain width (mm); GR - grain length-width ratio; EC - extract content (\%) 
Line 18/1-7 had significantly higher uniformity of grains, extract content, 1000-grain weight and grain length and width than Zagorets (Table 2). Higher extract content, starch content, 1000-grain weight, and grain length compared to the parent was found in line18/25 .

Table 2. Physical and chemical characteristics of grain of barley mutant lines and the parent variety Zagorets

\begin{tabular}{|c|c|c|c|c|c|c|c|c|}
\hline $\begin{array}{l}\text { Mutant line/ } \\
\text { Parent }\end{array}$ & GU & $\mathrm{PC}$ & $\mathrm{SC}$ & TGW & GL & GW & GR & $\mathrm{EC}$ \\
\hline Zagorets & 90.65 & 11.39 & 58.02 & 44.75 & 8.41 & 3.23 & 2.60 & 77.15 \\
\hline $18 / 1-4$ & 89.54 & 12.69 & 58.04 & 43.75 & 8.20 & 3.22 & 2.55 & 76.55 \\
\hline $18 / 1-5$ & 89.45 & 11.74 & 56.79 & 43.75 & 7.78 & 3.52 & 2.21 & 76.90 \\
\hline $18 / 1-6$ & 84.45 & 11.88 & 58.33 & 42.75 & 8.06 & 3.18 & 2.53 & 78.30 \\
\hline $18 / 1-7$ & 92.85 & 11.59 & 59.09 & 46.00 & 9.25 & 3.69 & 2.51 & 79.65 \\
\hline $18 / 2-2$ & 91.50 & 11.53 & 59.33 & 45.25 & 9.05 & 3.40 & 2.66 & 78.10 \\
\hline $18 / 2-3$ & 89.55 & 11.56 & 58.12 & 44.50 & 8.17 & 3.13 & 2.61 & 75.65 \\
\hline $18 / 2-5$ & 90.05 & 11.34 & 59.50 & 46.75 & 9.29 & 3.45 & 2.69 & 79.05 \\
\hline $18 / 2-6$ & 90.60 & 12.08 & 57.58 & 45.00 & 8.50 & 3.28 & 2.59 & 76.70 \\
\hline $18 / 3-2$ & 90.85 & 12.07 & 57.66 & 44.75 & 8.48 & 3.41 & 2.49 & 77.75 \\
\hline $18 / 3-7$ & 85.60 & 12.76 & 56.90 & 42.50 & 7.49 & 2.87 & 2.61 & 77.80 \\
\hline LSD 0.05 & 1.19 & 0.65 & 1.41 & 1.17 & 0.59 & 0.26 & 0.19 & 1.37 \\
\hline
\end{tabular}

GU - grains uniformity (\%); PC - protein content (\%); SC - starch content (\%). TGW - 1000-grain weight (g); GL - grain length (mm); GW - grain width (mm); GR - grain length-width ratio; EC - extract content (\%)

Mutant line 17/2-14 had higher grain uniformity and starch content and lower protein content that parent variety Asparuh (Table 3). Significantly higher grain uniformity and 1000-grain weight and lower protein content were found in line 17/2-19. Higher 1000-grain weight than in the parent was also measured in line 17/2-1. Higher and lower grain length-width ratio was observed in $17 / 2-17$ and 17/2-12 respectively.

Table 3. Physical and chemical characteristics of grain of barley mutant lines and the parent variety Asparuh

\begin{tabular}{lllllllll}
\hline $\begin{array}{l}\text { Mutant line/ } \\
\text { Parent }\end{array}$ & GU & PC & SC & TGW & GL & GW & GR & EC \\
\hline Asparuh & 90.80 & 11.99 & 57.58 & 45.00 & 8.90 & 3.57 & 2.49 & 78.90 \\
$17 / 1-5$ & 89.70 & 12.37 & 58.64 & 44.50 & 8.75 & 3.39 & 2.58 & 76.75 \\
$17 / 1-8$ & 91.19 & 12.14 & 57.37 & 44.75 & 8.79 & 3.41 & 2.58 & 78.85 \\
$17 / 1-15$ & 87.65 & 11.59 & 57.60 & 44.25 & 7.67 & 3.19 & 2.40 & 77.20 \\
$17 / 2-1$ & 91.75 & 12.22 & 57.69 & 46.75 & 8.86 & 3.50 & 2.53 & 79.40 \\
$17 / 2-3$ & 91.50 & 12.24 & 57.29 & 45.00 & 9.13 & 3.55 & 2.57 & 77.65 \\
$17 / 2-12$ & 89.65 & 11.79 & 57.73 & 43.25 & 7.42 & 3.44 & 2.16 & 77.10 \\
$17 / 2-14$ & 93.07 & 10.99 & 59.53 & 45.50 & 9.09 & 3.50 & 2.60 & 79.70 \\
$17 / 2-16$ & 91.05 & 12.44 & 57.56 & 45.25 & 8.51 & 3.41 & 2.50 & 78.70 \\
$17 / 2-17$ & 87.80 & 12.37 & 57.78 & 43.25 & 8.69 & 3.20 & 2.72 & 77.70 \\
$17 / 2-19$ & 93.45 & 11.35 & 56.33 & 48.50 & 9.38 & 3.65 & 2.57 & 79.55 \\
LSD 0.05 & 1.21 & 0.58 & 1.53 & 1.25 & 0.61 & 0.32 & 0.21 & 1.22 \\
\hline
\end{tabular}

GU - grains uniformity (\%); PC - protein content (\%); SC - starch content (\%). TGW - 1000-grain weight (g); GL - grain length (mm); GW - grain width (mm); GR - grain length-width ratio; EC - extract content (\%) 
Mutant line 15/1-9 showed higher grain uniformity, grain length, and grain lengthwidth ratio than parent variety Imeon (Table 4). Line 15/1-17 had higher grain uniformity, 1000-grain weight, grain length, grain lengthwidth ratio, and extract content and lower protein content than Imeon. Significantly lower protein content was also found in line 15/3-2.

The correlation coefficient between studied grain quality traits are presented in Table 5. Grain uniformity exhibited positive significant correlation with 1000-grain weight $(\mathrm{r}=0.655)$, grain length $(\mathrm{r}=0.513)$ grain width $(\mathrm{r}=0.495)$ and extract content $(\mathrm{r}=0.355)$. Protein content was negatively associated with starch content $(\mathrm{r}=-0.359)$ and extract content $(\mathrm{r}=-0.328)$. A significant correlation between starch content and extract content ( $\mathrm{r}=0.352)$ was found. The 1000 -grain weight had positive and significant correlation with grain length $(\mathrm{r}=0.771)$, grain width $(\mathrm{r}=0.718)$ and extract content $(\mathrm{r}=0.473)$. The grain length was positively associated with grain width $(\mathrm{r}=0.764)$, grain length-width ratio $(\mathrm{r}=0.483)$ and extract content $(\mathrm{r}=0.434)$. A positive association between grain width and extract content $(\mathrm{r}=0.353)$ was observed.

The dendrogram of the studied mutant lines and parent varieties is presented in Figure 1. The mutant lines and their parents were grouped into 5 clusters based on studied traits related to grain quality. Cluster I united 11 genotypes and had two subclusters. The first subcluster consisted of parent variety Asparuh, two lines from Asparuh (17/1-8 and 17/2-136), two lines from Zagorets (18/2-2 and 18/2-5) and two lines from Kuber (16/1-4 and 16/113). The second subcluster included parent variety Imeon and three mutants from this variety (15/3-7, 15/1-2, and 15/1-3). Cluster II had 12 genotypes and was also divided into two subclusters. Variety Zagorets and two mutants from Zagorets (18/2-6 and 18/3-2) along with two mutants from Kuber (16/1-21 and 16/2-1), one from Asparuh (17/2-3) and one from Imeon (15/3-6) were included in the first subcluster. The second subcluster consisted of variety Kuber and four lines obtained from this patent $(16 / 1-14,16 / 3-12$, 16/1-1, and 16/1-8). Cluster III was formed from 8 mutant lines - two from Imeon (15/118 and 15/1-8), two from Kuber (16/2-12 and 16/3-8), three from Asparuh (17/2-1, 17/2-14 and 17/3-2) and one from Zagorets (18/1-7). Cluster IV included two mutants from Zagorets (18/1-6 and 18/3-7). Cluster V consisted of 14 mutant lines - four from Imeon (15/3-2, 15/1$12,15 / 2-3$ and 15/1-8), three from Kuber (16/1-10, 16/1-3 and 16/3-14), four from Asparuh (17/2-12, 17/1-5, 17/1-15 and 17/2$17)$ and thee from Zagorets (18/1-5, 18/1-4 and 18/2-3).

Table 4. Physical and chemical characteristics of grain of barley mutant lines and the parent variety Imeon

\begin{tabular}{lllllllll}
\hline $\begin{array}{l}\text { Mutant line/ } \\
\text { Parent }\end{array}$ & GU & PC & SC & TGW & GL & GW & GR & EC \\
\hline Imeon & 89.15 & 12.13 & 58.62 & 44.50 & 7.91 & 3.39 & 2.33 & 78.35 \\
$15 / 1-2$ & 89.75 & 12.74 & 57.79 & 43.62 & 7.87 & 3.41 & 2.31 & 79.25 \\
$15 / 1-3$ & 88.75 & 11.72 & 57.63 & 45.25 & 7.86 & 3.31 & 2.37 & 78.90 \\
$15 / 1-8$ & 87.95 & 12.19 & 56.21 & 44.25 & 7.75 & 3.48 & 2.23 & 73.45 \\
$15 / 1-9$ & 92.35 & 12.22 & 58.27 & 45.50 & 8.96 & 3.39 & 2.64 & 79.40 \\
$15 / 1-12$ & 88.00 & 11.97 & 57.81 & 43.75 & 6.61 & 2.73 & 2.42 & 77.35 \\
$15 / 1-17$ & 93.00 & 10.77 & 57.92 & 46.75 & 9.19 & 3.55 & 2.59 & 79.95 \\
$15 / 2-3$ & 88.50 & 11.67 & 58.38 & 41.50 & 5.63 & 2.38 & 2.37 & 77.00 \\
$15 / 3-2$ & 89.75 & 10.87 & 58.34 & 42.75 & 7.15 & 3.00 & 2.38 & 77.45 \\
$15 / 3-6$ & 90.85 & 12.39 & 58.17 & 45.25 & 7.73 & 3.41 & 2.27 & 76.15 \\
$15 / 3-7$ & 90.35 & 12.49 & 58.68 & 44.75 & 7.36 & 3.12 & 2.36 & 78.75 \\
$L S D 0.05$ & 1.23 & 0.57 & 1.12 & 1.28 & 0.67 & 0.29 & 0.19 & 1.37 \\
\hline GU -9.29
\end{tabular}

GU - grains uniformity (\%); PC - protein content (\%); SC - starch content (\%). TGW - 1000-grain weight (g); GL - grain length (mm); GW - grain width (mm); GR - grain length-width ratio; EC - extract content (\%) 
DYULGEROVA B., et al.

Table 5. Correlation coefficients between physical and chemical characteristics of grain of barley mutant lines

\begin{tabular}{llllllll}
\hline Traits & $\begin{array}{l}\text { Protein } \\
\text { content }\end{array}$ & $\begin{array}{l}\text { Starch } \\
\text { content }\end{array}$ & $\begin{array}{l}\text { 1000- } \\
\text { grain } \\
\text { weight }\end{array}$ & $\begin{array}{l}\text { Grain } \\
\text { length }\end{array}$ & $\begin{array}{l}\text { Grain } \\
\text { width }\end{array}$ & $\begin{array}{l}\text { Grain } \\
\text { length- } \\
\text { width } \\
\text { ratio }\end{array}$ & $\begin{array}{l}\text { Extract } \\
\text { content }\end{array}$ \\
\hline Grain uniformity & -0.126 & 0.115 & $0.655^{* *}$ & $0.513^{* *}$ & $0.495^{* *}$ & 0.107 & $0.355^{*}$ \\
$\begin{array}{l}\text { Protein content } \\
\text { Starch content }\end{array}$ & & $-0.359^{*}$ & -0.208 & -0.081 & -0.124 & 0.084 & $-0.328^{*}$ \\
$\begin{array}{l}\text { 1000-grain weight } \\
\text { Grain length }\end{array}$ & & 0.057 & 0.110 & 0.014 & 0.121 & $0.352^{*}$ \\
$\begin{array}{l}\text { Grain width } \\
\text { Grain length-width }\end{array}$ & & & $0.771^{* *}$ & $0.718^{* *}$ & 0.187 & $0.473^{* *}$ \\
ratio & & & & $0.764^{* *}$ & $0.483^{* *}$ & $0.434^{* *}$ \\
\hline
\end{tabular}

"correlation is significant at the 0.05 level; ${ }^{* *}$ correlation is significant at the 0.01 level

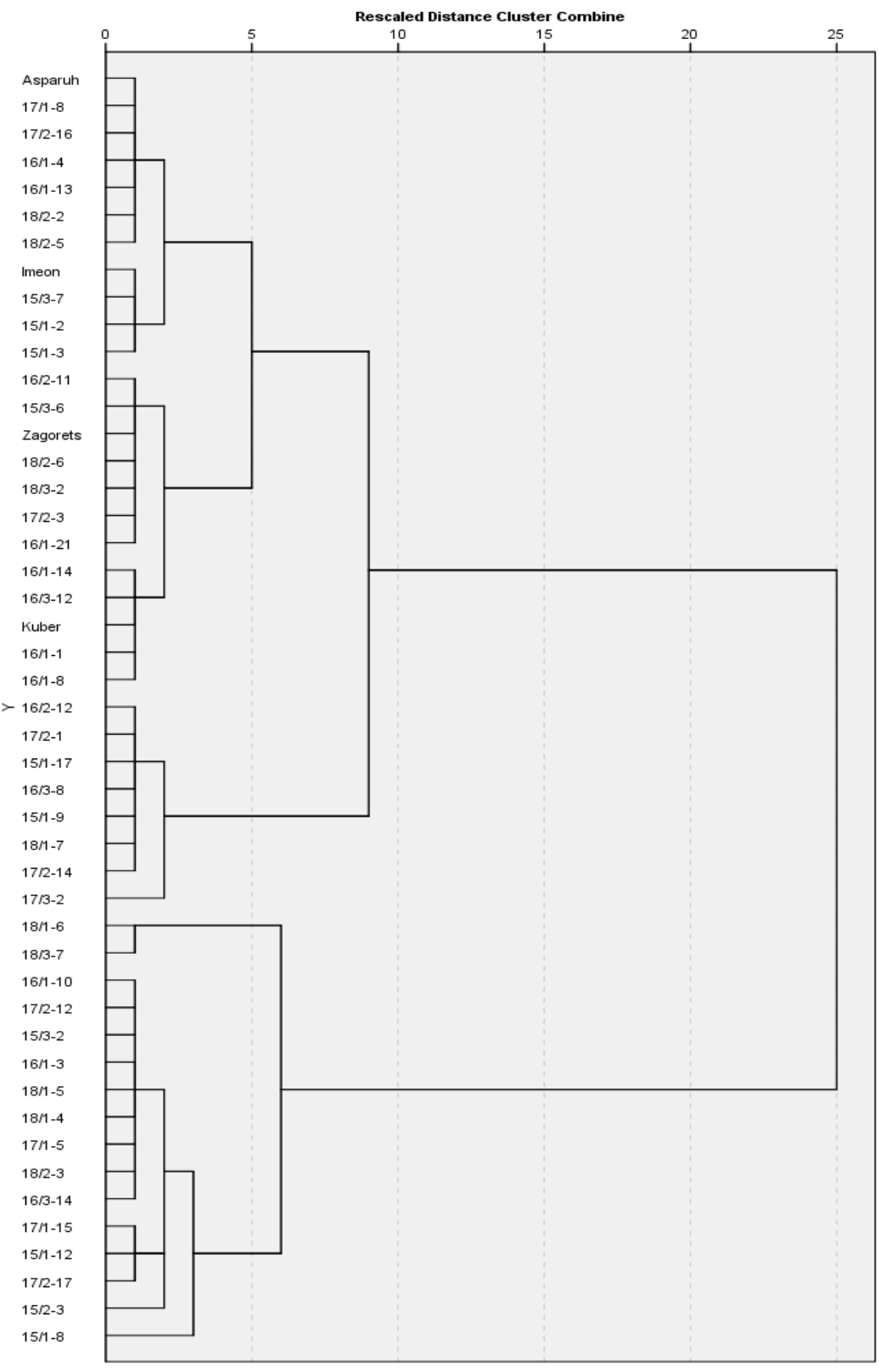

Figure 1. Cluster analysis of 43 mutant lines and their parent varieties based on grain traits related to malting quality 
Comparison of cluster means of studied traits revealed that clusters III recorded the highest value for uniformity of grains, extract content, 1000 -grain weight, grain length and width, and lowest for protein content (Table 6). Cluster
IV had the lowest cluster means for uniformity of grains, 1000-grain weight, grain width, and highest protein content. The cluster mean for extract content was lowest for cluster V.

Table 6. Cluster means of grain traits related to malting quality

\begin{tabular}{llllll}
\hline Traits & I $(11)^{*}$ & II (12) & III (8) & IV (2) & V (14) \\
\hline Grain uniformity (\%) & 90.49 & 91.63 & 92.68 & 85.03 & 89.09 \\
Protein content (\%) & 11.96 & 12.31 & 11.67 & 12.32 & 12.02 \\
Starch content (\%) & 58.35 & 57.48 & 58.28 & 57.62 & 57.87 \\
1000-grain weight (g) & 44.90 & 44.85 & 46.41 & 42.63 & 43.54 \\
Grain length (mm) & 8.35 & 8.32 & 9.07 & 7.78 & 7.63 \\
Grain width (mm) & 3.33 & 3.33 & 3.62 & 3.03 & 3.13 \\
Grain length-width ratio & 2.51 & 2.51 & 2.51 & 2.57 & 2.44 \\
Extract content (\%) & 78.70 & 77.11 & 79.58 & 78.05 & 76.65 \\
\hline
\end{tabular}

*in brackets - number of genotypes included in cluster

\section{DISCUSSION}

Grain uniformity is an important characteristic of barley malting quality. Uniform grain absorbs water more evenly during malting and has a low protein content, which provides high-quality malt. Barley used for malting should have more than $85 \%$ uniformity of grain (20). In the present study, all parent varieties and mutant lines except line 18/1-6 showed grain uniformity above this value. Six mutant lines with significantly higher grain uniformity compared to parents (18/1-7 from Zagorets, 17/2-14 and 17/2-19 from Asparuh, 15/1-9, 15/1-17 and 15/3-7 from Imeon) were found.

The protein content is one of the important parameters in selecting malting barley. It is affected by genotype, cultural practices, and growing environments. Malt barley with high protein content results in lower extracts. It also downs water uptake during steeping, potentially affecting final malt quality. A very low protein level, on the other hand, results in a lack of enzymes necessary to modify the barley kernel and to break down the starch during brewing. Low protein also impairs the brewing performance due to poor yeast amino acid nutrition. The desirable range of protein is between 9.0-12.0\% for 2-rowed barley. Only four mutant lines 16/1-4 from Kuber, 17/2-14 from Asparuh, 15/1-17, and 15/3-2 from Imeon had significantly lower protein content than the corresponding parent variety. For the period of study almost half of the mutant lines as well parent Imeon showed a higher mean value of protein than the recommended for malting barley. The high protein content is a common problem for malting grain that is produced in particular weather conditions because of the high temperature during grain filling.

Starch content in barley grain is one of the most important quality parameters for malting barley because, during malting and mashing, the starch degrades to fermentable sugars that can be utilized by the brewing yeasts (21). In the current study, six mutant lines (16/1-4, $16 / 1-13, \quad 16 / 2-12$ and 16/3-14 from Kuber;18/2-5 from Zagorets;17/2-14 from Asparuh) with significantly higher mean starch content than parent varieties were observed.

Thousand-grain weight is associated with the content of extract in malt (22). Mutant lines 16/2-12 from Kuber, 18/2-5 from Zagorets, 17/2-1 and 17/2-19 from Asparuh, 15/1-17 from Imeon had significantly higher 1000grain weight. Laghari et al. (23) also found wheat mutant lines with higher 1000-grain weight.

Grain size is another important character for barley malting quality. The size and shape of grain affect uptake and distribution of water in the endosperm during germination and therefore influence the rate and uniformity of malting. Large grain usually is characterized with high starch content and hence produces malt with more extract (24). Mutant lines differed significantly from parent varieties for grain length, grain width, and grain lengthwidth ratio was found. Changes in shape and 
size of grain after mutation treatment was also reported in rice (25-27) and wheat (28).

The most important character for selecting varieties suitable for malting is malt extract content. Significantly higher extract content compered to parent variety was measured in mutant lines 16/2-12 and 16/3-8 from Kuber; 18/1-7 and 18/2-5 from Zagorets; 15/1-17 from Imeon. High-quality winter malting barley varieties should have extract content higher than $79 \%$. During the study period, 11 of mutant lines had extract content higher than $79 \%$, while four parent varieties showed extract content below this value. The content of malt extract is a complex trait influenced by a number of genes, environmental factors, and their interaction. In the present study, extract content was positively associated with grain uniformity, 1000-grain weight, grain length and width, and starch content and negative with protein content. Similar correlations between the malt extract and other quality traits have been also observed in previous studies (29-31).

The forty-three mutant lines and their parent varieties were grouped into five clusters in Ward's method. The mutants originated from the same parent were grouped into different clusters indicated that the sodium azide treatment induced different types of changes in the grain characteristics. The cluster with the highest uniformity of grains, extract content, 1000-grain weight, grain length and width, and lowest for protein content (Cluster III) included only mutant lines indicated that the mutation treatment was efficient for improvement of traits related to malt quality.

\section{CONCLUSIONS}

Significant variation among barley mutant lines for studied physical and chemical traits of grain related to the grain quality of malting barley was found. Mutant lines with higher extract content (16/2-12 and 16/3-8 from Kuber; 18/1-7 and 18/2-5 from Zagorets; 15/117 from Imeon), grain uniformity (18/1-7 from Zagorets; 17/2-14 and 17/2-19 from Asparuh; 15/1-9, 15/1-17 and 15/3-6 from Imeon), 1000grain weight (16/2-12 from Kuber; 18/2-5 from Zagorets; 17/2-1 and 17/2-19 from Asparuh; 15/1-17 from Imeon), and lower protein content (16/1-4 from Kuber; 17/2-14 from Asparuh; 15/1-17 and 15/3-2 from Imeon) in grain compared to parent varieties were found. Those mutant lines can be used as germplasm in the breeding program for the development of high-quality malting varieties. The improvement of extract content of mutant lines was associated with increased grain uniformity, starch content, grain size, and 1000 grain weight and reduced protein content. Cluster analysis showed that mutants originated from the same parent were grouped into different clusters indicated that the sodium azide treatment effectively induced diverse types of changes in the grain characteristics.

\section{REFERENCES}

1. Pathirana, R., Plant mutation breeding in agriculture. Plant sciences reviews, 6(032):107-126, 2011.

2. van Harten, A. M., Mutation breeding: theory and practical applications. Cambridge University Press, UK, 1998.

3. Ahloowalia, B. S., Maluszynski, M., and Nichterlein, K., Global impact of mutationderived varieties. Euphytica, 135(2):187204, 2004.

4. Molina-Cano, J. L., de Togores, F. R., Royo, C., and Perez, A., Fast-germinating low $\beta$-glucan mutants induced in barley with improved malting quality and yield. Theoretical and Applied Genetics, 78(5):748-754, 1989.

5. Bhatty, R. S., and Rossnagel, B. G., Zero amylose lines of hull-less barley. Cereal Chemistry, 74(2):190-191, 1997.

6. Morell, M. K., Kosar-Hashemi, B., Cmiel, M., Samuel, M. S., Chandler, P., Rahman, S., Buleon, A., Batey, I. L. and Li, Z., Barley sex6 mutants lack starch synthase IIa activity and contain a starch with novel properties. The Plant Journal,34(2):173185, 2003.

7. Eggum, B. O., Protein quality of induced high lysine mutants in barley. In: Friedman M. (ed) Nutritional Improvement of Food and Feed Proteins. Springer, Boston, MA, pp. 317-341, 1978.

8. Balaravi, S. P., Bansal, H. C., Eggum, B. O., and Bhaskaran, S., Characterisation of induced high protein and high lysine mutants in barley. Journal of the Science of Food and Agriculture, 27(6):545-552, 1976.

9. Raboy, V., Young, K. A., Dorsch, J. A., and Cook, A., Genetics and breeding of seed phosphorus and phytic acid. Journal of plant physiology, 158(4):489-497, 2001.

10.Erdal, K., Proanthocyanidin-free barleymalting and brewing. Journal of the Institute of Brewing, 92(3):220-224, 1986. 
11.Baik, B. K., and Ullrich, S. E., Barley for food: characteristics, improvement, and renewed interest. Journal of cereal science, 48(2):233-242, 2008.

12.Hirota, N., Kaneko, T., Kuroda, H., Kaneda, H., Takashio, M., Ito, K., and Takeda, K., Characterization of lipoxygenase-1 null mutants in barley. Theoretical and applied genetics, 111(8):1580-1584, 2005.

13.Talamè, V., Bovina, R., Sanguineti, M. C., Tuberosa, R., Lundqvist, U., Salvi, S., TILLMore, a resource for the discovery of chemically induced mutants in barley. Plant Biotechnol. J., 6:477-485, 2008.

14.Vulchev, D., and Dyulgerova, B., IZ Bori new winter feed barley variety. Bulgarian Journal of Crop Science, 5:427-430, 2011.

15.Dyulgerova, B. and Vulchev, D., Characteristics of winter feed barley variety Bozhin. Bulgarian Journal of Crop Science 2:62-66, 2012.

16.Abràmoff, M. D., Magalhães, P. J., Ram, S. J., Image processing with ImageJ. Biophoton Int. 11:36-42, 2004.

17.Gothard, P. G., Morgan, A. G., Smith, D. B., Evaluation of a micro-malting procedure used to aid a plant breeding programme. Journal of the Institute of Brewing 86: 69-73, 1980.

18.Ward, J. H., Hierarchical grouping to optimize an objective function. J. Am. Stat. Assoc., 58:236-244, 1963.

19.SPSS Inc., SPSS for Windows. Release 16.0.SPSS Inc. Chicago, IL. USA, 2007.

20.Schwarz, P., and Li, Y., Malting and brewing uses of barley. In: Ullrich SE (ed.), Barley: Production, improvement, and uses, Oxford Wiley-Blackwell, UK, pp 478-521, 2010.

21.Fangel, J. U., Eiken, J., Sierksma, A., Schols, H. A., Willats, W. G., and Harholt, J. Tracking polysaccharides through the brewing process. Carbohydrate polymers, 196:465-473, 2018.

22.Edney, M. J., Izydorczyk, M. S., Symons, S. J., and Woodbeck, N., Measuring barley kernel colour and size to predict end use malt quality. Canadian Grain Commission [Online] Available: http://www. grainscanada. $\quad g c . \quad$ ca/researchrechercheledney/bcsq-ctoq/bcsq-ctoq-eng. htm, 2005.
DYULGEROVA B., et al.

23.Laghari, K. A., Sial, M. A., Arain, M. A., Khanzada, S. D., and Channa, S. A., Evaluation of stable wheat mutant lines for yield and yield associated traits. Pakistan Journal of Agriculture, Agriculture Engineering, Veterinary Sciences, 28(2):124-130, 2012.

24.Fox, G. P., Panozzo, J. F., Li, C. D., Lance, R. C. M., Inkerman, P. A. and Henry, R. J., Molecular basis of barley quality. Aus. J. Agri. Res., 54:1081-1101, 2003.

25.Bari, G., Mustafa, G., Soomro, A. M., and Baloch, A. W., Studies on the yield performance and grain quality of mutant strains of rice. Pak. J. Bot, 13(2):189-194, 1981.

26.Soomro, A. M., Baloch, A. W., Ahmed, M., Javed, M. A., Bughio, H. R., Bughio, M. S., Muhammad, T. and Mastoi, N. N., Evaluation of Induced Mutants of Rice for Yield and Quality Characters. Sciences, 1(3):248-249, 2002.

27.Kakar, K., Xuan, T. D., Quan, N. V., Wafa, I. K., Tran, H. D., Khanh, T. D., and Dat, T. D., Efficacy of N-methyl-N-nitrosourea (MNU) Mutation on Enhancing the Yield and Quality of Rice. Agriculture, 9(10), 212, 2019.

28. Kenzhebayeva, S., Doktyrbay, G., Sarsu, F., Omirbekova, N., Abekova, A., and Tashenev, D., Mutant Resources of Spring Wheat to Improve Grain Quality and Morphology. In: Fahad S., Basir A. and Adnan M. (eds) Global Wheat Production, IntechOpan, London, UK, pp. 165-181, 2018.

29.Sarkar, B. , Verma, R. P. S. and Mishra, B., Association of important malting traits in barley (Hordeum vulgare). Indian Journal of Agricultural Sciences, 78:853-857, 2008.

30.Verma, R. P. S. , Sarkar, B., Gupta, R. and Varma, A., Breeding barley for malting quality improvement in India. Cereal Research Communication, 36: 135-145, 2008.

31.Kumar, V., Verma, R. P. S., Kumar, D., Kharub, A. S., and Sharma, I., Association of malting quality attributes under timely and late sown conditions in barley (Hordeum vulgare L.). Journal of Wheat Research, 6(2):167-170, 2014. 